\title{
Association of cag E Gene and LL-37 Serum Level with Helicobacter pylori-induced Peptic Ulceration in Egyptian Patients
}

Amany M Ibrahim ${ }^{1 *}$, Rehab M Atef ${ }^{2}$, Shymaa A Mansour ${ }^{3}$, Marwa A Mansour ${ }^{3}$, Islam M Ibrahim ${ }^{4}$ and Tarik I Zaher ${ }^{5}$

${ }^{1}$ Internal Medicine Department, Faculty of Medicine, Zagazig University, Egypt

${ }^{2}$ Clinical Pathology Department, Faculty of Medicine, Zagazig University, Egypt

${ }^{3}$ Medical Microbiology and Immunology Department, Faculty of Medicine, Zagazig University, Egypt

${ }^{4}$ General Surgery Department, Faculty of Medicine, Zagazig University, Egypt

${ }^{5}$ Tropical Medicine Department, Faculty of Medicine, Zagazig University, Egypt

\begin{abstract}
Background and aim: Variation in the clinical outcome of Helicobacter pylori (H. pylori) induced pathology is multifactorial, involving a complex interplay between the host immune responses and pathogen virulence factors.

Patients and methods: This study included $95 \mathrm{H}$. pylori infected patients who underwent endoscopy. They selected if culture and/or histopathological examination and rapid urease test were positive. All patients were examined for presence of cag $E$ and LL-37.

Results: Endoscopic findings in the patients were variable. The most frequent findings was gastritis $45.3 \%$ (43/95), followed by duodenitis; $36.8 \%$ (35/95), duodenal ulcer; $14.7 \%(14 / 95)$, esophagitis; $11.6 \%(11 / 95)$ and the least frequent one was gastric ulcer; $4.2 \%$ (4/95). Interestingly, cag $E$ was positive in $27.4 \%$ of patients (26/95). As regards LL-37, its mean \pm SD was $123.25 \pm 20.26 \mathrm{ng} / \mathrm{mL}$. Classifying studied patients into peptic ulcer and non peptic ulcer groups, cag $E$ was positive in patients with peptic ulcer more than those who were non peptic $(88.9 \%$ versus $13 \%)(\mathrm{OR}=0.019 ; \mathrm{Cl} 0.004-0.094)$ and $\mathrm{P}<0.001$. The difference between two groups as regard LL-37 was statistically significant $(\mathrm{Cl} 44.87-51.98), \mathrm{P}<0.001$.
\end{abstract}

Conclusion: This study concluded that there was a strong association of cag $E$ and LL-37 serum level with $H$. pylori-induced peptic ulceration in Egyptian patients.

Keywords: Cag E gene; LL-37 Serum level; Helicobacter pylori; Peptic ulceration; Egyptian patients

\section{Introduction}

Helicobacter pylori (H. pylori) is a gram negative, non-spore forming spiral bacterium which colonizes the human stomach [1]. $H$. pylori is prevalent worldwide; nearly $50 \%$ of the population is infected with $H$. pylori. The prevalence, incidence, age distribution and sequels of infection are significantly different in developed and developing countries [2]. One Egyptian study in rural area found the overall seropositivity rate of $91.7 \%$ when screened for anti- $H$. pylori antibodies among six hundred and five people [3]. Individuals infected with $H$. pylori have a 10 to $20 \%$ lifetime risk of developing peptic ulcers and a 1 to $2 \%$ risk of acquiring stomach cancer $[4,5]$ and type B low-grade mucosal-associated lymphoma [6]. Furthermore, the organism is also thought to be involved in other human illnesses such as hematologic and autoimmune disorders, insulin resistance and the metabolic syndrome [7-9].

Variation in the clinical outcome of $H$. pylori induced pathology is multifactorial, involving a complex interplay between the host immune responses and pathogen virulence factors. Several putative genes, such as cytotoxin associated gene (Cag)A, CagE, vacuolating cytotoxin A (vacA), induced by contact with epithelium (iceA) and blood-group antigen-binding adhesion (babA2), have been identified and are likely to play an important role in the pathogenicity of the bacterium [10-12]. Cag E is shown to increase secretion of chemokines, such as interleukin (IL)-8, from infected host epithelial cells [13-15]. IL-8 is a potent neutrophil chemoattractant and so could mediate the initial host inflammatory response to $H$. pylori infection, present in infected gastric mucosa [16].
As regards host immune factors against $H$. pylori infections, the innate production of proteins and peptides with antimicrobial activity by gastric epithelial cells provides a layer of host innate defense $[17,18]$. Cathelicidins; a family of host defense peptides are naturally expressed by cells of the gastrointestinal tract (GIT). The single known cathelicidin in man is human cationic antibacterial protein of $18 \mathrm{kDa}$ (hCAP18), whose C-terminal 37 amino acid peptide is termed LL-37. LL-37 is proteolytically cleaved to be released as a functional antimicrobial peptide. LL-37/hCAP18 has a distinct distribution in the intestinal tract, with its expression being greatest in the surface and upper crypt epithelium in the colon and sparse to absent in small intestinal epithelium, with the exception of Brunner's glands in duodenum [19]. In normal stomach, the expression of LL-37/hCAP18 is restricted to differentiated surface of various types of cells including epithelial cells, chief cells and parietal cells and is also present in the stomach secretion. It is upregulated during infection, inflammation and wound healing both in animals and humans [19-22]. The increasing level of LL-37 may help fighting bacterial infection at the early stage. However, during the

${ }^{*}$ Corresponding author: Dr. Amany Mohamed Ibrahim, Department of Internal Medicine, Zagazig University Faculty of Medicine, Zagazig 44519, Egypt, Tel: +2055-2338335; E-mail: dramanymibrahim@gmail.com

Received September 08, 2015; Accepted September 14, 2015; Published September 16, 2015

Citation: Ibrahim AM, Atef RM, Mansour SA, Mansour MA, Ibrahim IM, et al. (2015) Association of cag E Gene and LL-37 Serum Level with Helicobacter pyloriinduced Peptic Ulceration in Egyptian Patients. J Medical Microbiol Diagnosis S5:002. doi:10.4172/2161-0703.S5-002

Copyright: (c) 2015 Ibrahim AM, et al. This is an open-access article distributed under the terms of the Creative Commons Attribution License, which permits unrestricted use, distribution, and reproduction in any medium, provided the original author and source are credited. 
progression from atrophic gastritis to adenocarcinoma, the expression of LL-37 is reduced [22].

On the other hand, the expression of LL-37 is low or absent in chronic ulcers, as when antibodies to this peptide was administrated, it may inhibit post wounding re-epithelialization [23].

This study aimed to detect whether there is an association of Cag $E$ and LL-37 serum level with $H$. pylori-induced peptic ulceration in Egyptian patients.

\section{Patients and Methods}

\section{Research design}

This Cross sectional study was conducted at Internal medicine, Clinical Pathology and Medical Microbiology and Immunology Departments, Faculty of Medicine, Zagazig University, Egypt during the period from April 2014 to June 2015. This study included $95 \mathrm{H}$. pylori infected patients. They were 64 males and 31 females and their ages were 32-55 years old. All patients underwent full history taking including dyspeptic symptoms; that includes epigastric pain, bloating, nausea, vomiting, early satiety and hematemesis and melena. Routine laboratory tests including urine and stool analysis, complete blood picture, erythrocyte sedimentation rate (ESR), liver and kidney function tests were done. Abdominal ultrasonography was also done to exclude any abdominal mass (inflammatory or cancers).

\section{Exclusion criteria}

Patients were excluded if they had recently (within the last 15 days) received antibiotics or had been treated for $H$. pylori in the last seven days, they use drugs as aspirin or NSAIDs which is a confounding variable in the development of gastritis and ulcer.. Also, excluded cases of any bacterial infection induced inflammation or GIT cancers.

\section{Ethical considerations}

This study was approved by medical ethical committee of Faculty of Medicine, Zagazig University. A written informed consent was obtained from all the patients.

\section{Diagnosis of the $H$. pylori infection}

All subjects were underwent endoscopy after overnight fasting using endoscope (GIF XQ230; Olympus, Center Valley, PA) for evaluation of dyspepsia and infection with $H$. pylori. Two biopsies were obtained; an antral biopsy about $2 \mathrm{~cm}$ of the pylorus and another from the corpus of the stomach for bacterial isolation [24]. For cultures to detect $H$. pylori, the specimens were transported to the laboratory in $0.2 \mathrm{~mL}$ of $20 \%$ glucose broth (BioMerieux) in sterile screw-capped tubes at $4^{\circ} \mathrm{C}$ within two hours. Before culture, the specimens were grounded and homogenized with a sterile mortar and pestle in $1 \mathrm{~mL}$ of saline. The biopsy homogenate was placed onto a Columbia blood agar plate with antibiotics supplement set; trimethoprim, vancomycin, and amphotericin B. The plates were incubated under microaerophilic conditions; $5 \% \mathrm{O}_{2}, 7.5 \% \mathrm{CO}_{2}, 7.5 \% \mathrm{H}_{2}$, and $80 \% \mathrm{~N}_{2}$ using Campy Pak microaerophilic system envelopes (Columbia Diagnostics, Springfield, VA) at $37^{\circ} \mathrm{C}$ for up to ten days. The plates were checked every other day for growth. On day 5 , the plates without obvious growth were subcultured onto Columbia blood agar plates to promote growth of lightly growing colonies that may have been missed visually. All colonies that were small, circular, and smooth colonies suggestive of $H$. pylori were tested with Gram-stain, oxidase, catalase, and urease tests to confirm the identification [25].
The H. pylori infection was considered positive if the culture and/or histopathological examination and rapid urease test were positive [26]. All the isolated $H$. pylori were suspended in $2 \mathrm{~mL}$ of tryptone soy broth medium containing $20 \%$ (vol/vol) glycerol and kept frozen at $-70^{\circ} \mathrm{C}$ until DNA extraction was performed [27].

\section{Detection of pathogenicity gene CagE by PCR:}

\section{Extraction of genomic DNA}

Chromosomal DNA was extracted from $H$. pylori isolates using a commercially available kit (QIAGEN Inc., Valencia, CA, USA) according to the manufacturer's guidelines.

\section{Genotyping of the CagE gene}

It was performed as described by Ikenoue et al. [28]. The distal regulatory region was amplified using the following primers that obtained from (Biolegio, Netherlands):

CagE-F1 5'-GCGATTGTTATTGTGCTTGTAG-3' and CagE-R1 5'-GAAGTGGTTAAAAAATCAATGCCCC-3'. Each PCR of Cag E was performed in a total volume of $50 \mu \mathrm{l}$ containing $100 \mathrm{ng}$ genomic DNA from $H$. pylori culture, $200 \mu \mathrm{M}$ each of dNTP, 1X PCRbuffer $(20$ mMTris- $\mathrm{HCl}, \mathrm{pH} 8.4), 50 \mathrm{mMKCl}, 1.5 \mathrm{mM} \mathrm{MgCl}, 0.5 \mu \mathrm{M}$ of each primer, and 1.5 units of Taq polymerase. Negative controls were added to each PCR run including all reagents except template DNA which was substituted with ultrapure water. PCR was performed in a heated lid thermal cycler )Biometra, Germany). PCR amplification conditions were optimized as follows: initial denaturation for $5 \mathrm{~min}$ at $94^{\circ} \mathrm{C}$ was followed by 40 cycles of denaturation at $90^{\circ} \mathrm{C}$ for $30 \mathrm{~s}$, annealing at $52^{\circ} \mathrm{C}$ for $30 \mathrm{~s}$, and extension at $70^{\circ} \mathrm{C}$ for $1 \mathrm{~min}$ and a final extension at $70^{\circ} \mathrm{C}$ for $10 \mathrm{~min}$.

Aliquots of amplified samples $(10 \mu \mathrm{l})$ were electrophoresed on $2 \%$ agarose gel in $1 \mathrm{X}$ TAE buffer (40 mMTris-acetate, $1 \mathrm{mM}$ EDTA [pH $8.0])$ containing ethidium bromide $(0.5 \mu \mathrm{g} / \mathrm{ml})$, and then the amplified bands (329 bp) were visualized under a UV transilluminator) Biometra, Germany).

\section{Determination of Cathelicidin LL-37 serum level}

It was measured by performing an enzyme-linked immunosorbent assay (ELISA) with commercially available kit (HK 321 Humman LL37 Elisa Kit, Hycult biotechnology, Uden. Netherlands). The minimum detectable concentration of serum LL-37 when using this assay was $0.1 \mathrm{ng} / \mathrm{mL}$.

\section{Statistical analysis}

All patients' data were tabulated, and then processed using Statistical Package for Sciences and Society SPSS (version-11). Odds ratios (OR) 95\% confidence intervals (CI) was calculated to assess the relative difference between non peptic ulcer and peptic ulcer groups (as regards Cag E) in H. pylori infected patients. The t-test was used to evaluate the age and LL-37 differences between the two groups. Also, 95\% confidence intervals (CI) was done regarding LL-37. Chi square and $\mathrm{P}$ value were used to calculate sex, Cag $E$ genotype frequency differences in the two groups (sex, Cag E). P value less than 0.05 were regarded as significant.

\section{Results}

This current study assessed whether Cag E and LL-37 serum level affected the outcome of $H$. pylori infection. The descriptive data of the patients were analyzed and presented in Table 1 . The study included $64(67.5 \%)$ male and $31(32.5 \%)$ female. Dyspeptic symptoms were 


\begin{tabular}{|c|c|c|}
\hline & $\mathrm{N}=95$ & $\%$ \\
\hline \multicolumn{3}{|l|}{ Sex } \\
\hline Male & 64 & $67.5 \%$ \\
\hline Female & 31 & $32.5 \%$ \\
\hline \multicolumn{3}{|l|}{ Symptoms } \\
\hline Nausea & 72 & $75.8 \%$ \\
\hline Vomiting & 70 & $73.7 \%$ \\
\hline Bloating & 60 & $63.1 \%$ \\
\hline Early satiety & 44 & $46.3 \%$ \\
\hline Epigastric pain & 35 & $36.8 \%$ \\
\hline Hematemesis and melena & 3 & $3.1 \%$ \\
\hline \multicolumn{3}{|l|}{ Endoscopic findings } \\
\hline Gastritis & 43 & $45.3 \%$ \\
\hline Duodenitis & 35 & $36.8 \%$ \\
\hline Duodenal ulcer & 14 & $14.7 \%$ \\
\hline Esophagitis & 11 & $11.6 \%$ \\
\hline Gastric ulcer & 4 & $4.2 \%$ \\
\hline \multicolumn{3}{|l|}{ Cag E } \\
\hline Present (+) & 26 & $27.4 \%$ \\
\hline Absent (-) & 69 & $72.6 \%$ \\
\hline \multicolumn{3}{|l|}{ LL-37 serum level (ng/mL) } \\
\hline Mean \pm SD & $123.25 \pm 20.26$ & \\
\hline
\end{tabular}

Table 1: Descriptive data (demographic, clinical, endoscopic findings, cag $E$ and LL-37 serum level) of studied patients.

\begin{tabular}{|c|c|c|c|c|}
\hline & $\begin{array}{c}\text { Non peptic } \\
\text { ulcer group } \\
\mathrm{N}=77\end{array}$ & $\begin{array}{l}\text { Peptic ulcer } \\
\text { group } \mathrm{N}=18\end{array}$ & OR $(95 \% \mathrm{Cl})$ & $\mathbf{P}$ \\
\hline Age ( 32-55) & $42.5 \pm 6.98$ & $41 \pm 7.5$ & - & 0.427 \\
\hline \multicolumn{5}{|l|}{ Sex } \\
\hline Male $(n=64)$ & $52(67.5 \%)$ & $12(66.7 \%)$ & \multirow[b]{2}{*}{-} & \multirow{2}{*}{0.575} \\
\hline Female $(n=31)$ & $25(32.5 \%)$ & $6(33.3 \%)$ & & \\
\hline \multicolumn{5}{|l|}{ Cag E } \\
\hline Present (+) & $10(13 \%)$ & $16(88.9 \%)$ & \multirow{2}{*}{$\begin{array}{c}0.019(0.004- \\
0.094)\end{array}$} & \multirow{2}{*}{$<0.001$} \\
\hline Absent (-) & $67(87 \%)$ & $2(11.1 \%)$ & & \\
\hline \multicolumn{5}{|c|}{ LL-37 serum level $(\mathrm{ng} / \mathrm{mL})$} \\
\hline Mean \pm SD & $84 \pm 5.8$ & $132.43 \pm 7.5$ & $(44.87-51.98)$ & $<0.001$ \\
\hline
\end{tabular}

Table 2: Differences between non peptic ulcer and peptic ulcer $H$. pylori patients groups as regards age, sex, cag $\mathrm{E}$ and LL-37 serum level.

variable where most frequent symptom was nausea $(\mathrm{n}=72,75.8 \%)$, followed by vomiting ( $\mathrm{n}=70,73.7 \%)$, bloating ( $\mathrm{n}=60,63.1 \%)$, early satiety $(n=44,46.3 \%)$ and epigastric pain $(n=35,36.8 \%)$ and the least frequent symptom was hematemesis and melena in about 3 patients only (3.1\%). As regards endoscopic findings, gastritis was the most frequent finding; $45.3 \%$ (43/95), followed by duodenitis; $36.8 \%$ (35/95), duodenal ulcer; $14.7 \%$ (14/95) and esophagitis; $11.6 \%$ (11/95) and the least frequent finding was gastric ulcer $4.2 \%$ (4/95). Interestingly, $C a g E$ was positive in $27.4 \%$ of patients (26/95). As regards LL-37, its mean \pm SD was 123.25 $\pm 20.26 \mathrm{ng} / \mathrm{mL}$. Table 2 shows that there was no statistically significant differences between non peptic ulcer and peptic ulcer groups as regards age and sex. Cag $E$ was positive in patients with peptic ulcer more than those who were non peptic ( $88.9 \%$ versus $13 \%)(\mathrm{OR}=0.019$; CI 0.004 $0.094)$ and $\mathrm{P}<0.001$. Moreover, the difference between the two groups as regard LL-37 was statistically significant (CI 44.87-51.98), $\mathrm{P}<0.001$.

\section{Discussion}

Helicobacter pylori, a bacterium adapted to colonize the gastric mucosa, is considered to be the main etiological agent of gastritis and also a risk factor for peptic ulcer and gastric cancer in humans [29,30]. Factors related to the host, the diversity of bacterial pathogenicity and the environment seem to be related to the broad clinical spectrum related to infection by $H$. pylori [31]. Cag E gene is one of virulence factor in the $H$. pylori organism affecting its pathogenesis potential effect in the gastric mucosa [32]. On the other hand, H. pylori upregulates LL-37/hCAP18 production by the gastric epithelium, suggesting that cathelicidin or its derivative LL-37 contributes to combat chronic infection with this gastric pathogen $[22,33]$. In this research, there was overlap between dyspeptic symptoms in studied patients. This work reported that most frequent endoscopic finding was gastritis $45.3 \%$ (43/95), followed by duodenitis; 36.8\% (35/95), duodenal ulcer; $14.7 \%$ (14/95) and esophagitis; $11.6 \%(11 / 95)$ and the least frequent finding was gastric ulcer $4.2 \%$ (4/95). In disagreement with our findings, another research in Kuwait, reported that $57.6 \%(57 / 99)$ of patients had gastritis, $61.6 \%(61 / 99)$ had duodenal ulcer and 1\% (1/99) had gastric ulcer [34]. The more aggressive endoscopic findings in studied patients in Kuwait more than Egypt may be due to host genetic or environmental difference between the two countries. As regards age and sex between non peptic ulcer and peptic ulcer groups, our results found no significance results.

The current study confirmed the role of Cag E as an important virulent factor related to $H$. pylori pathogenicity as we detected significance difference between the two groups regarding its prescence $(\mathrm{P}<0.001)$. This was in concordance with other studies that showed the presence of Cag E-positive isolates were associated with duodenal ulceration. For instance, in a study by Fallone et al. [35], 31 (37\%) out of 84 patients with gastroduodenal disease (including both peptic ulceration and gastric cancer) were infected with Cag E-positive strains, compared with only $20.7 \%$ of 92 patients with gastritis alone $(\mathrm{P}=0.02)$. Also, our results matched with that of Ramis et al. [33] as they detected that $\operatorname{Cag} E$ is a biomarker for gastric lesions and increasing pathogenic potential of $H$. pylori infection. In addition, Day et al. [36] detected that 12 out of 13 children (92\%) with duodenal ulcers were infected with Cag E-positive isolates, compared with only 5 out of $16(31 \%)$ with gastritis alone. Although French study found that 51 out of 56 (91\%) strains isolated from patients with duodenal ulcers were Cag E-positive, whereas 13 out of 17 (76\%) H. pylori isolates obtained from patients with gastritis alone were positive but with non statistically significant difference between duodenal ulcer and gastritis patents [37]. This difference was explained as different geographic location of the patients may affect the results of the studies. It is clear that Helicobacter isolates in humans from different regions of the world are variable $[38,39]$.

Regarding LL-37, our study found significant increase in LL-37 serum level in peptic ulcer group more than non peptic ulcer group. This in accordance with another study that estimated the level of LL-37 in gastric secretion. In addition, many previous studies interested in role of LL-37 in promotion of mucosal repair in GIT [40], mentioned that, during inflammation, LL-37 decrease pathogenic microbes, inflammatory cytokines and apoptosis, increase mucus secretion by activation of MAP kinase, formyl peptide receptor and mucin genes with electrostatic interaction on microbial membrane [41-44]. On the other hand, in presence of ulceration, it leads to increase cell proliferation, re-epithelialization and angiogenesis by activation of growth factors and their receptors $[21,45,46]$.

As Cag E and LL-37 have a significant role in pathogenic progress of $H$. pylori infection, dealing in the future with these results may help to treat H. pylori and stopping its pathogenic progress. Also, supplementation with this host defense peptide as LL-37 orally seems to be a promising approach to treat different disorders in the GIT. 
Citation: Ibrahim AM, Atef RM, Mansour SA, Mansour MA, Ibrahim IM, et al. (2015) Association of cag E Gene and LL-37 Serum Level with Helicobacter pylori-induced Peptic Ulceration in Egyptian Patients. J Medical Microbiol Diagnosis S5:002. doi:10.4172/2161-0703.S5-002

\section{Conclusion}

This study concluded that there is high impact of Cag $E$ and serum LL-37 on pathogenicity and severity of $H$. pylori infection in Egyptians.

\section{Recommendation}

We recommended other studies that deal with other factors affecting the aggressive attitude of $H$. pylori infection and other trials to use new strategy in treatment of this infection.

\section{References}

1. Smolka AJ, Backert S (2012) How Helicobacter pylori infection controls gastric acid secretion. J Gastroenterol 47: 609-618.

2. Torres J, Pérez-Pérez G, Goodman KJ, Atherton JC, Gold BD, et al. (2000) A comprehensive review of the natural history of Helicobacter pylori infection in children. Arch Med Res 31: 431-469.

3. El Dine SS, Mubarak M, Salama R, El Raziky M, El Sherbiny E, et al. (2008) Low Seroprevalence of Anti-CagA Antibodies Inspite of High Seroprevalence of Anti-H.pylori Antibodies in Rural Egyptian Community. Res J Med Med Sci 3: $118-23$.

4. Chang $\mathrm{AH}$, Parsonnet $\mathrm{J}$ (2010) "Role of Bacteria in Oncogenesis". Clinical Microbiology Reviews 23: 837-857.

5. Kusters JG, van Vliet AH, Kuipers EJ (2006) "Pathogenesis of Helicobacter pylori Infection”. Clin Microbiol Rev 19 (3): 449-90.

6. Asaka M, Dragosics BA (2004) Helicobacter pylori and gastric malignancies. Helicobacter 9 Suppl 1: 35-41.

7. Hasni SA (2012) Role of Helicobacter pylori infection in autoimmune diseases. Curr Opin Rheumatol 24: 429-434.

8. Eshraghian A, Hashemi SA, Hamidian Jahromi A, Eshraghian H, Masoompour SM, et al. (2009) Helicobacter pylori infection as a risk factor for insulin resistance. Dig Dis Sci 54: 1966-1970.

9. Gunji T, Matsuhashi N, Sato H, Fujibayashi K, Okumura M, et al. (2008) Helicobacter pylori infection is significantly associated with metabolic syndrome in the Japanese population. Am J Gastroenterol 103: 3005-3010.

10. Cover TL (1996) The vacuolating cytotoxin of Helicobacter pylori. Mol Microbio 20: $241-246$

11. Peek Jr RM, Thompson SA, Donahue JP, Tham KT, Atherton JC, et al. (1998) Adherence to gastric epithelial cells induces expression of a Helicobacter pylor gene, iceA, that is associated with clinical outcome. Proc Assoc Am Physicians 110: $531-544$.

12. Gerhard M, Lehn N, Neumayer N, Borén T, Rad R, et al. (1999) Clinical relevance of the Helicobacter pylori gene for blood-group antigen-binding adhesin. Proc Natl Acad Sci USA 96: 12778-12783.

13. Censini S, Lange C, Xiang Z, Crabtree JE, Ghiara P, et al. (1996) Cag, a pathogenicity island of Helicobacter pylori, encodes type I-specific and diseaseassociated virulence factors. Proc Natl Acad Sci USA 93: 14648-53.

14. Tummuru MK, Sharma SA, Blaser MJ (1995) Helicobacter pylori picB, a homologue of the Bordetella pertussis toxin secretion protein, is required for induction of IL-8 in gastric epithelial cells. Mol Microbiol 18: 867-76.

15. Segal ED, Lange C, Covacci A, Tompkins LS, Falkow S (1997) Induction of host signal transduction pathways by Helicobacter pylori. Proc Natl Acad Sci USA 94: 7595-7599.

16. Bodger K, Crabtree JE (1998) Helicobacter pylori and gastric inflammation. $\mathrm{Br}$ Med Bull 54: 139-50.

17. Hamanaka Y, Nakashima M, Wada A, Ito M, Kurazono H, et al. (2001) Expression of human beta- defensin 2 (hBD-2) in Helicobacter pylori induced gastritis: antibacterial effect of hBD-2 against Helicobacter pylori. Gut 49: 481-487.

18. Hase K, Murakami M, limura M, Cole SP, Horibe Y, et al. (2003) Expression of LL-37 by human gastric epithelial cells as a potential host defense mechanism against Helicobacter pylori. Gastroenterology 125: 1613-1625.

19. Hase K, Eckmann L, Leopard JD, Varki N, Kagnoff MF (2002) Cell differentiation is a key determinant of cathelicidin LL-37/human cationic antimicrobial protein 18 expression by human colon epithelium. Infect Immun 70: 953-963.
20. Wong CC, Zhang L, Ren SX, Shen J, Chan RL, et al. (2011) Antibacterial peptides and gastrointestinal diseases. Curr Pharm Des 17: 1583-1586.

21. Yang YH, Wu WK, Tai EK, Wong HP, Lam EK, et al. (2006) The cationic host defense peptide rCRAMP promotes gastric ulcer healing in rats. J Pharmaco Exp Ther 318: 547-554.

22. Hase K, Murakami M, limura M, Cole SP, Horibe Y, et al. (2003) Expression of LL-37 by human gastric epithelial cells as a potential host defense mechanism against Helicobacter pylori. Gastroenterology 125: 1613-1625.

23. Heilborn JD, Nilsson MF, Kratz G, Weber G, Sørensen O, et al. (2003) The cathelicidin antimicrobial peptide LL-37 is involved in re-epithelialization of human skin wounds and is lacking in chronic ulcer epithelium. J Invest Dermatol 120: $379-389$

24. Perdichi-Zzi G, Bottari, Pallio S, Fera MT, Carbone M, et al. (1996) Gastric infection by Helicobacter pylori and antral gastritis in hyperglycemia obese and diabetic subjects. New Microbiol 19: 149-54

25. Megraud F (1997) How should Helicobacter pylori infection be diagnosed? Gastroenterology 113(6suppl): S93-8.

26. Anastiosis R, Goritsas C, Papamihail C, Trigidou R, Garzonis P, et al. (2002) Helicobacter pylori infection in diabetic patients: prevalence and endoscopic findings. Eur J Intern Med 13: 376-9.

27. Henry I Characterization of pathogenic microorganisms by genomic fingerprinting with arbitrarily primed PCR. In: Essential Procedures doe Clinical microbiology. ASC. Washington, DC. pp. 658-60.

28. Ikenoue TS, Maeda KO, Gura M, Akanuma Y, Mitsuno, et al. (2001) Determination ofHelicobacterpylorivirulence by simple gene analysis of the Cagpathogenicity island. Clin Diagn Lab Immunol 8: 181-186.

29. Godoy APO, Miranda MCB, Paulino LC, Mendonça S, Ribeiro ML, et al. (2007) Análise das Impressões digitais de DNA e de fatores de virulência de linhagens de Helicobacter pylori. Arq Gastroenterol 44: 107-112.

30. Miszputen SJ, Guias de (2007) Medicina Ambulatorial e Hospitalar UNIFESP. (2rdedn), Barueri(SP), Manoli.

31. Kusters JG, Van Vliet AHM, Kuipers EJ (2006) Pathogenesis of Helicobacter pylori Infection. Clin Microbiol Rev 19: 449-490.

32. Ramis IR, Vianna JS, Junior LV, Groll AV, Almeida da Silva PE (2013) CagE as a biomarker of the pathogenicity of Helicobacter pylori. Revista da Sociedade Brasileira de Medicina Tropical. 46: 185-189.

33. Hamanaka Y, Nakashima M, Wada A, Ito M, Kurazono H, et al. (2001) Expression of human beta-defensin 2 (hBD-2) in Helicobacter pylori induced gastritis: antibacterial effect of hBD-2 against Helicobacter pylori. Gut 49: 481-487.

34. Siddique L, Al-Qabandi A, Al-Ali J, Alazmi W, Memon A, et al. (2014) Association between Helicobacter pylori genotypes and severity of chronic gastritis, peptic ulcer disease and gastric mucosal interleukin-8 levels: Evidence from a study in the Middle East. Gut Pathogens 6: 41.

35. Fallone CA, Beech R, Barkun A, M Göttke, V Loo, et al. (1998) The Helicobacter pylori CagE gene is associated with gastroduodenal disease [abstract]. Can $\mathrm{J}$ Gastroenterol 12: 111A.

36. Day AS, Jones NL, Lynett JT, Jennings HA, Fallone CA, et al. (2000) Cag E Is a Virulence Factor Associated with Helicobacter pylori-Induced Duodenal Ulceration in Children. The Journal of Infectious Diseases 181: 1370-5.

37. Jenks PJ, Megraud F, Labigne A (1998) Clinical outcome after infection with Helicobacter pylori does not appear to be reliably predicted by the presence of any of the genes of the Cag pathogenicity island. Gut 43: 752-8.

38. Pan ZJ, Berg DE, van der Hulst RW, Wan-Wen Su, Ausra Raudonikiene, et al. (1998) Prevalence of vacuolating cytotoxin production and distribution of distinct vacA alleles in Helicobacter pylori from China. J Infect Dis 178: 220-6.

39. Akopyanz N, Bukanov NO, Westblom TU, Kresovich S, Berg DE (1992) DNA diversity among clinical isolates of Helicobacter pylori detected by PCR based RAPD fingerprinting. Nucleic Acids Res 20: 5137-42.

40. Chow JYC, Li L J, Wu WKK, Cho CH (2013) Cathelicidin a potential therapeutic peptide for gastrointestinal inflammation and cancer. World J Gastroenterol 19: 2731-2735.

41. Wu WK, Wong CC, Li ZJ, Zhang L, Ren SX, et al. (2010) Cathelicidins in inflammation and tissue repair: Potential therapeutic applications for gastrointestinal disorders. Acta Pharmacol Sin 31: 1118-1122. 
Citation: Ibrahim AM, Atef RM, Mansour SA, Mansour MA, Ibrahim IM, et al. (2015) Association of cag E Gene and LL-37 Serum Level with Helicobacter pylori-induced Peptic Ulceration in Egyptian Patients. J Medical Microbiol Diagnosis S5:002. doi:10.4172/2161-0703.S5-002

Page 5 of 9

42. Schweizer $F$ (2009) Cationic amphiphilic peptides with cancerselective toxicity. Eur J Pharmacol 625: 190-194.

43. Ahluwalia A, Tarnawski AS (2013) Cathelicidin gene therapy: a new therapeutic option in ulcerative colitis and beyond? Gene Ther 20: 119-120.

44. Raqib R, Sarker P, Bergman P, Ara G, Lindh M, et al. (2006) Improved outcome in shigellosis associated with butyrate induction of an endogenous peptide antibiotic. Proc Natl Acad Sci USA 103: 9178-9183.

45. Li J, Post M, Volk R, Gao Y, Li M, et al. (2000) PR39, a peptide regulator of angiogenesis. Nat Med 6: 49-55.

46. Dorschner RA, Pestonjamasp VK, Tamakuwala S, Ohtake T, Rudisill J, et al. (2001) Cutaneous injury induces the release of cathelicidin anti-microbia peptides active against group A Streptococcus. J Invest Dermatol 117: 91-97. 